\title{
Por que a pedagogia do oprimido de Paulo Freire incomodava? Alceu Ravanello Ferraro
}

\section{Resumo}

Tendo como referência a experiência de alfabetização de adultos conduzida por Paulo Freire em Angicos (RN), em 1963, desenvolve-se uma reflexão sobre suas concepções, seu método de alfabetização e suas experiências, fortemente vinculadas aos movimentos sociais do final dos anos 1950 e início dos anos 1960, com destaque para aquilo que se consubstanciaria em seu livro Pedagogia do oprimido, de 1970. O objetivo é desvelar as razões da repressão contra Freire e os movimentos sociais associados à sua proposta pedagógica e pôr à luz a mistificação que envolveu a pretensa "pedagogia dos homens livres", do Movimento Brasileiro de Alfabetização (Mobral), em confronto com a pedagogia do oprimido, de Freire. Conclui-se revelando o tamanho do desafio que o século 20 legou para o século 21 no que se refere à superação do analfabetismo.

Palavras-chave: Paulo Freire; movimentos sociais; alfabetização; repressão; Mobral. 


\section{Abstract \\ Why was Paulo Freire's Pedagogy of the Oppressed considered a threat?}

Based on a reference to the adult literacy teaching experience carried out by Paulo Freire at Angicos, Rio Grande do Norte, in 1963, this article develops thoughts on his concepts and method of teaching literacy, and his experiences that are strongly connected to the social movements of the end of the 1950's and beginning of the 1960's, highlighting what would be expressed in his 1970 book, Pedagogy of the Oppressed. Its purpose is to uncover the reasons for repression against Freire and the social movements associated with his pedagogical proposal, and to shed light on the mistification that involved the claimed "pedagogy of free men", of MOBRAL, in a confrontation with Freire's "pedagogy of the oppressed". It concludes revealing the size of the challenge bequeathed by the $20^{\text {th }}$ century to the $21^{\text {st }}$ century, as regards overcoming illiteracy.

Keywords: Paulo Freire; social movements; literacy; MOBRAL.

Por que a pedagogia do oprimido de Paulo Freire incomodava a ditadura militar e seus apoiadores civis? A resposta é simples: porque desacomodava. Pessoas que desacomodam, incomodam. Essa situação vinha de bem antes da publicação do livro Pedagogia do oprimido, escrito no exílio no Chile, em 1968, e publicado sucessivamente em tradução para o inglês nos Estados Unidos, para o espanhol no México e no original em português, no Brasil, todos em 1970. Justamente no ano em que começava a operar o Movimento Brasileiro de Alfabetização (Mobral), obra e braço da ditadura militar instalada no País com o golpe de 1964.

Na minha avaliação, o que ouriçou os espíritos golpistas contra Freire, assim como contra o seu método ou sistema, não foi só a experiência em si de alfabetização de adultos, realizada em Angicos, no interior do Rio Grande do Norte, no curto período de 28 de janeiro a 2 de abril de 1963. Foram também as condições em que tal experiência foi realizada, entre as quais vale lembrar as seguintes: a total autonomia exigida por Freire na condução da experiência; a participação da União Estadual de Estudantes, na pessoa de seu presidente, o líder universitário Marcos Guerra; a exigência de não interferência de parte do órgão financiador, a Aliança para o Progresso; o compromisso exigido do governo do Estado de não utilizar politicamente a iniciativa; o envolvimento de Freire com os movimentos sociais; e, por fim, a presença do presidente João Goulart no encerramento da experiência de alfabetização.

Nada melhor que examinar a posição do embaixador norte-americano Lincoln Gordon para se entender por que e quanto Freire e seu método incomodavam. Na realidade, tudo isso que incomodava tinha muito a ver com o que sugere a conhecida canção infantil que diz: 
Um elefante incomoda muita gente

Dois elefantes incomodam, incomodam muito mais [...]

Dez elefantes incomodam, incomodam, incomodam, incomodam, incomodam, incomodam, incomodam, incomodam, incomodam, incomodam muito mais.

A única diferença é que, no Brasil da primeira metade dos anos 1960, não se tratava de elefantes, mas de movimentos sociais. Se, como o elefante da canção, um movimento social já incomoda, imagine o quanto poderiam incomodar 74 movimentos sociais reunidos:

No início dos anos 60, como parte da ampla mobilização popular/populista, movimentos de cultura e educação espalharam-se por todo o Brasil. O I Encontro de Alfabetização e Cultura Popular, realizado no Recife em setembro de 1963, registrou a participação de 74 desses movimentos, dos quais 44 trabalhavam com a alfabetização de adultos (Souza, 1987, p. 17). Representavam uma ameaça ao conservadorismo e uma possibilidade de mudança efetiva, conforme sugerem vários indícios. [...] Um dos objetivos principais era alfabetizar (e conscientizar) milhares de pessoas pelo Método Paulo Freire, de modo que estivessem aptas a desencadear a "revolução pelo voto" nas eleições presidenciais de 1965. (Scocuglia, 2001, p. 23-24).

Nos anos que antecederam o golpe, conscientização e politização, termoschave da pedagogia de Freire, faziam parte do cotidiano dos mais diversos movimentos sociais. O Movimento de Educação de Base (MEB) de Natal, por exemplo, promovera, em 1962, a Campanha de Politização que provocara, já antes do golpe, uma reação violenta de parte do patronato rural:

A primeira reação de vulto se fez sentir em 1962, quer no sentido de impedir a sindicalização dos trabalhadores sindicalizados, quer expulsando da propriedade líderes sindicais, trabalhadores sindicalizados e famílias de monitores de Escola Radiofônica engajados na Campanha de Politização. Não é possível determinar o volume dessa ação repressiva. Duas centenas de cartas de 1962, por nós lidas, revelaram que dez famílias de monitores haviam sido despejadas por conta de voto ou sindicado. (Ferrari[o], ${ }^{1}$ 1968, p. 201).

Para a reação, tratava-se de subversão, desde que se entenda que a subversão de que eram acusados os sindicatos consistia "na luta pela substituição da ordem de fato pela ordem de direito, isto é, das normas tradicionais que de fato regulavam as relações de trabalho no meio rural, pelas normas de direito previstas no Código Civil e no Estatuto do Trabalhador Rural". Essa reação patronal, por sua vez, "consistia precisamente na luta pela manutenção da ordem de fato, ou seja, pela sobrevivência do sistema tradicional de relações de trabalho e, inclusive, de fidelidades políticas" (Ferrari[o], 1968, p. 205 - grifos do autor).

Não deve, pois, ser motivo de perplexidade a brusca mudança de opinião do então embaixador americano, aquele mesmo que ajudaria a organizar e sustentar o golpe desferido na primeira madrugada de abril de 1964. Se, num primeiro impulso irrefletido, pudera vislumbrar na experiência de Angicos um possível trampolim para a vitória contra a fome, as enfermidades e o analfabetismo, o embaixador soube logo reconsiderar sua primeira avaliação, passando a ver nessa experiência nada menos que o embrião de um movimento subversivo, voltado para a conscientização

$\overline{1}$ Em 1992, por determinação judicial, o sobrenome do autor foi retificado, passando de Ferrari para Ferraro. 
e politização, "associando-o aos métodos de Hitler, Stalin e Peron"(!) (Streck, 2010, p. 43). Afinal, como poderia o senhor embaixador admitir que o professor Paulo Freire se recusasse a subordinar ao controle da Aliança para o Progresso a experiência realizada em Angicos e seus prováveis desdobramentos? Com o agravante, como já disse, da presença do presidente João Goulart no encerramento dos trabalhos! Essa aproximação entre governo (federal, no caso) e movimentos populares não podia não incomodar o senhor Gordon e a articulação de forças, civis e militares, que já estavam armando o golpe. ${ }^{2}$

Mas que movimentos eram esses? Não apenas movimentos, também acontecimentos ou fatos novos, trazendo mudança, mesmo que não revolucionária. Para responder a essa pergunta, há que partir dos anos 1950. No dizer de Moacir de Góes (1980, p. 45), se o assunto é educação popular e de adultos, "os anos 60 [...] começam de 1958, no II Congresso Nacional de Educação de Adultos". E, citando Vanilda Paiva (1973), o autor esclarece que é nesse ano que ocorre uma reintrodução da reflexão sobre o social na elaboração das ideias pedagógicas, coisa que se perdera, de um modo geral, desde a década de 1920.

Nesse âmbito, pode-se listar toda uma série de acontecimentos e mudanças que foram tendo lugar e de iniciativas que foram sendo tomadas no período prégolpe, nos planos internacional, nacional e regional, reunidas aqui de diversas fontes (Góes, 1980; Germano, 1982; Ferrari[o], 1968; Wanderley, 1984; Ferraro, 1999; Scocuglia, 2001; Fávero, 2006), sem qualquer pretensão de apresentar uma relação completa.

No plano internacional, temos a Revolução Cubana (1959); a Aliança para o Progresso (1961) e seus polos anti-Jango e anti-Arraes no Brasil; a Encíclica Mater et Magistra, de 15 de maio de 1961, que atualizou as orientações da Igreja Católica sobre a questão social, e o Concílio Vaticano II, convocado por João XXIII em 25 de dezembro de 1961.

No plano nacional, vale lembrar a Campanha Nacional de Erradicação do Analfabetismo (1958); a Superintendência do Desenvolvimento do Nordeste (Sudene - 1959); o Movimento de Educação de Base (MEB - 1961), resultante de convênio entre a Conferência Nacional dos Bispos do Brasil (CNBB) e a Presidência da República; a União Nacional de Estudantes (UNE) e a criação, por esta, do Centro Popular de Cultura (CPC - 1961); a Campanha das Reformas de Base do governo Goulart; a Frente de Mobilização Popular; e o IV Congresso Latino-Americano de Estudantes.

No plano regional (Nordeste), cabe mencionar:

- o crescente descontentamento popular na região;

- a chegada de Miguel Arraes à prefeitura do Recife e de Djalma Maranhão à de Natal (1956);

- a consciência que se formara do Nordeste como região explosiva;

- a eleição da oposição para o governo do Rio Grande do Norte (1956) e para os governos da Bahia e de Pernambuco (1958);

\footnotetext{
${ }_{2}$ Para mais informações sobre a relação entre Freire, o governo do Estado do Rio Grande do Norte e a Aliança para o Progresso, pode-se consultar os itens 6, 7 e 8 do Capítulo I "O pré-64", em Aprendendo com a própria história, de Paulo Freire e Sérgio Guimarães (2001, p. 22-29).
} 
- a dura seca de 1958, oportunidade de aproximação e colaboração entre bispos do Nordeste e a Presidência da República;

- criação das primeiras escolas radiofônicas, em Natal (1958);

- ampliação das atividades do Serviço de Assistência Rural da Arquidiocese de Natal (1958);

- criação das Ligas Camponesas de Francisco Julião, em Pernambuco (1958);

- nova vitória da oposição no governo do Rio Grande do Norte (1960);

- início da sindicalização rural no Rio Grande do Norte promovida pela Igreja (1960);

- criação do Movimento de Cultura Popular (MCP) de Pernambuco (1960);

- eleição de Djalma Maranhão como primeiro prefeito de Natal por voto direto (1962);

- eleição de Miguel Arraes para o governo de Pernambuco (1962);

- as sucessivas etapas de construção do Método Paulo Freire ou Sistema Paulo Freire de alfabetização (desde 1955);

- a campanha De Pé no Chão Também se Aprende a Ler, em Natal (1961);

- a Campanha de Educação Popular (Ceplar), na Paraíba (1961).

Mesmo reconhecendo que 1958 não caiu do céu, Moacir de Góes (1980, p. 46) entende que esse ano "foi o pórtico por onde passaram os movimentos de educação popular dos anos 60". O autor diz também que o posicionamento tomado nesse congresso de 1958 iria retornar com Freire em 1959; que, em 1961, nasceria o Método Paulo Freire no Centro de Cultura Dona Olegarinha, do MCP, no Poço da Panela, no Recife, "fruto de 15 anos de acumulação de experiências do educador pernambucano no campo da educação de adultos, em áreas proletárias e subproletárias, urbanas e rurais" (p. 50), e que, em 1963, viria a experiência de alfabetização realizada por Freire em Angicos, com a participação do líder acadêmico Marcos Guerra.

Enfim, coisa demais para não incomodar, especialmente num país que sempre havia tratado os movimentos sociais com políticas e ações de repressão, quando não de puro e simples extermínio. Em síntese, como dizem os autores de Sociedade brasileira: uma história através dos movimentos sociais, "a grande maioria dos livros de História do Brasil procura ocultar a violência, sobretudo das autoridades, contra reivindicações das camadas populares, visando projetar a imagem de brasileiro cordial [...]", o que, na realidade, "[...] resulta inclusive na minimização - e até na ocultação - do que tem sido uma constante na nossa história: a luta dos setores populares contra a violenta repressão empregada pelos governantes" (Aquino et al., 2000, p. 289-290). Num segundo volume, que chega a ultrapassar mil páginas, os autores tratam da repressão aos movimentos no período mais recente: da crise do escravismo até o apogeu do neoliberalismo (Aquino et al., 2002).

A esse respeito, nada mais eloquente do que o testemunho de Euclides da Cunha em relação ao extermínio operado em Canudos, no sertão baiano, nos anos de 1896 e 1897: 
Canudos não se rendeu. Exemplo único em toda a História, resistiu até ao esgotamento completo. Expugnado palmo a palmo, na precisão integral do termo, caiu no dia 5, ao entardecer, quando caíram os seus últimos defensores, que todos morreram. Eram quatro apenas: um velho, dois homens feitos e uma criança, na frente dos quais rugiam raivosamente cinco mil soldados.

Caiu o arraial a 5. No dia 6 acabaram de o destruir desmanchando-lhe as casas, 5.200, cuidadosamente contadas. (Cunha, 2002, p. 587-588).

Coisa semelhante aconteceu na Guerra do Contestado, em Santa Catarina, "um dos maiores conflitos rurais no Brasil", como se lê em O Contestado: a práxis educativa de um movimento social, de Geraldo Antônio da Rosa (2011, p. 15), estudo desenvolvido à luz da Teologia da Libertação e da Educação Libertadora: "Nossos camponeses morreram... 4, 8, 10 ou 20 mil neste conflito rural. Não, eles não morreram. O sonho de liberdade, de emancipação permanece na memória dos vivos que hoje lutam para a construção de uma outra história" (p. 121).

Comparando, o autor diz que a Guerra de Canudos aconteceu num espaço mais delimitado e que os acontecimentos que lá tiveram lugar "foram imortalizados através de uma das grandes obras clássicas da literatura brasileira - Os sertões, de Euclides da Cunha [...]", enquanto que "[...] o Contestado ainda não foi suficientemente explorado devido à sua complexidade enquanto movimento social" (Rosa, 2011, p. 227-228).

Basta percorrer a obra já citada (Aquino et al., 2000, 2002), que quis ser uma história da sociedade brasileira à luz dos movimentos sociais, para se ter uma ideia da quantidade e diversidade dessa sucessão de movimentos na história do Brasil, desde o período colonial, todos reprimidos, quando não massacrados.

O seguinte diálogo entre Sérgio Guimarães e Paulo Freire mostra muito bem por que, para este, a alfabetização não se reduzia à aquisição do domínio das técnicas de ler e escrever:

Sérgio - Na sua passagem pela cadeia você teve oportunidade de alfabetizar
alguém?
Paulo - Não, mas houve comigo um caso interessante, na minha primeira passagem.
Um dia, à noitinha, um jovem tenente, dos que tratavam a gente com
decência, cortesmente, veio à cela onde eu estava e disse: "Professor, eu
vim conversar com o senhor porque agora nós vamos receber um grupo de
recrutas, e entre eles há uma quantidade enorme de analfabetos. Por que o
senhor não aproveita a sua passagem por aqui e ajuda a gente a alfabetizar
esses rapazes?" Olhei para o tenente e disse: "Mas, meu querido tenente, eu
estou preso exatamente por causa disso! Está havendo uma irracionalidade
enorme no país hoje, e se o senhor fala nessa estória de que vai convidar o
Paulo Freire para alfabetizar os recrutas, o senhor vai para a cadeia também.
Não dá." E ele: "Puxa, mas é assim?" Claro, não deu. (Freire, Guimarães,
2001, p. 49).

No meu entender, uma das obras mais importantes de Freire, pelo menos para a discussão sobre analfabetismo e alfabetização, é Ação cultural para a liberdade e outros escritos, que inicia com três textos produzidos no exílio, no Chile, em 1968, seguidos do texto "Ação cultural para a libertação", produzido em 1969 nos Estados Unidos. Neles, o autor começa desenvolvendo o que ele chama de crítica da visão 
ingênua (ou astuta) e de compreensão da visão crítica do analfabetismo e da alfabetização (Freire, 2001b).

Aqui, para se entender o alcance da crítica movida por Freire às concepções vigentes sobre analfabetismo, faz-se necessário um pouco de história. Em primeiro lugar, como diz Vanilda Paiva (1990, p. 9), na maior parte da nossa história, o analfabetismo não se colocara como problema, o que só aconteceu no final do Império, quando da reforma eleitoral para introdução do voto direto com a Lei Saraiva, de 9 de janeiro de 1881, que:

- ignorou a questão do acesso das mulheres ao voto;

- manteve o censo econômico da Constituição (a comprovação de uma renda mínima de 200 mil réis) como critério de admissão ao voto, endurecendo, inclusive, os mecanismos de comprovação;

- adicionou novo e poderoso critério que, sozinho, passou a excluir do voto 80\% da população masculina - os analfabetos (Ferraro, 2009, Capítulo 3).

A questão que, nos anos de 1879 e 1880, mais mobilizou os debates na Câmara dos Deputados entre a maioria liberal e a pequena minoria, também ela liberal, foi se os analfabetos podiam/deviam ou não votar. Em trabalho recente, em coautoria com bolsista de iniciação científica, os argumentos invocados pela maioria liberal dos ministérios Sinimbu e Saraiva contra o voto dos analfabetos foram sintetizados nas seguintes palavras: "o analfabetismo passa, de repente, a ser identificado com a condição de ignorância, de cegueira, de pauperismo, de falta de inteligência e discernimento intelectual e, por isso tudo, de incapacidade política", e ainda: "o analfabetismo ganha também a conotação de marginalidade e periculosidade" (Ferraro, Leão, 2012, p. 104).

Ao final se esclarece:

\begin{abstract}
Sabe-se que a maioria do povo brasileiro no momento em que se deu a reforma eleitoral era composta de analfabetos. O objetivo real da exigência de saber ler e escrever para ser eleitor não era purificar as urnas, como se pregava, mas sim impedir o alargamento da participação popular. A identificação negativa dos analfabetos como ignorantes, cegos, dependentes, incapazes e até perigosos demonstra o medo que a elite brasileira, em sua maior parte latifundiária e escravista, tinha de qualquer alargamento do direito de voto.
\end{abstract}

Assim, o estabelecimento da condição de saber ler e escrever para poder votar arredou das urnas, por mais de um século, a grande massa analfabeta. Mas [...] o processo de exclusão dos analfabetos do direito de voto se fez acompanhar de um processo de estigmatização dos "portadores" da condição de analfabetismo, que se traduziu em exclusão social. (Ferraro, Leão, 2012, p. 108).

É claro, entre a Lei Saraiva de 1881 e o ano de 1968 decorrera tempo bastante para que se pudesse ampliar a já extensa lista daquilo que Paulo Freire (2001, p. 16) chama de concepções distorcidas, que eu chamo de desconceitos (Ferraro, 2004) e que Ana Maria de Oliveira Galvão e Maria Clara Di Pierro (2007) chamam de preconceitos sobre o analfabetismo e sobre os "portadores" dessa condição - o que permite dizer que a condição de analfabeto ou analfabeta foi transformada em estigma, no sentido que Erving Goffman (1988) dá ao termo, a saber, de marca ou 
rótulo que desvaloriza, deprecia, desacredita o portador. A propósito, logo no início do primeiro texto de Freire de 1968 tem-se o seguinte:

\begin{abstract}
A concepção, na melhor das hipóteses, ingênua do analfabetismo o encara ora como uma "erva daninha" - daí a expressão corrente: "erradicação do analfabetismo"-, ora como uma "enfermidade" que passa de um a outro, quase por contágio, ora como uma "chaga" deprimente a ser "curada" e cujos índices, estampados nas estatísticas dos organismos internacionais, dizem mal dos níveis de "civilização" de certas sociedades. Mais ainda, o analfabetismo aparece também, nesta visão ingênua ou astuta, como a manifestação da "incapacidade" do povo [,] de sua "pouca inteligência", de sua "proverbial preguiça". (Freire, 2001a, p. 15)
\end{abstract}

Segundo Freire, essa compreensão limitada do problema do analfabetismo, "cuja complexidade não capta ou esconde [...]", só é capaz de oferecer respostas de "caráter mecanicista", isto é, uma alfabetização que "[...] se reduz ao ato mecânico de 'depositar' palavras, sílabas e letras nos alfabetizandos [...]", fazendo da palavra como que um amuleto, "[...] quase sempre sem relação com o mundo e com as coisas que nomeia", e do alfabetizador, alguém que "vai 'enchendo' o alfabetizando com suas palavras" (Freire, 2001a, p. 15-16).

Outra distorção é a concepção messiânica, que vê o analfabeto como "homem perdido" e a alfabetização como "salvação" (Freire, 2001a, p. 16).

E como é que Freire concebe o analfabetismo e a alfabetização? Para a concepção crítica, o analfabetismo não é uma chaga, nem uma erva daninha, nem uma enfermidade, é antes "uma das expressões concretas de uma realidade social injusta". E ainda: "não é um problema estritamente linguístico nem exclusivamente pedagógico, metodológico, mas político, como a alfabetização por meio da qual se pretende superá-lo. Proclamar sua neutralidade, ingênua ou astutamente, não afeta em nada a sua politicidade intrínseca". O aprendizado de que os alfabetizandos mais necessitam "não é escrever e ler 'a asa é da ave'", mas sim "o de 'escrever' a sua vida, o de 'ler' a sua realidade, o que não será possível se não tomam a história nas mãos para, fazendo-a, por ela ser feitos e refeitos". O que, segundo o autor, "não se faz por meio de blá-blá-blá, mas do respeito à unidade entre prática e teoria" (Freire, 2001a, p. 18-19).

Na sequência, Freire dirige sua crítica contra mais algumas concepções distorcidas a respeito do analfabetismo e, por consequência, da alfabetização. A primeira é a concepção "digestiva" ou "nutricionista" do conhecimento, tão comum nas cartilhas e na prática pedagógica, em que os analfabetos são considerados 'subnutridos', "não no sentido real em que muitos o são - esclarece o autor -, mas porque lhes falta o 'pão do espírito'". A segunda é a do analfabetismo como vergonha: "Pedro não sabia ler. Pedro vivia envergonhado. [...] Pedro agora sabe ler, por isso, está feliz." A terceira é o entendimento do analfabetismo como inferioridade: "Submetidos aos mitos da cultura dominante, entre eles o de sua 'natural inferioridade', não percebem, quase sempre, a significação real de sua ação transformadora sobre o mundo" (Freire, 2001a, p. 53-55, 59).

Por outro lado, na visão crítica freireana, aprender a ler e escrever "já não é, pois, memorizar sílabas, palavras ou frases, mas refletir criticamente sobre o próprio processo de ler e escrever e sobre o profundo significado da linguagem" (Freire, 2001a, p. 59). 
Na segunda parte do texto "Ação cultural para a libertação", Freire trata da "Ação cultural e conscientização". Ali continuam a suceder-se conceitos e propostas incomodativas, tais como:

- existência em e com o mundo;

- consciência de e sobre a realidade;

- papel que pode jogar a cultura no processo de libertação das classes oprimidas;

- cultura do silêncio;

- superação da compreensão mágica dos fatos;

- capacidade de refazer a leitura da (sua) realidade;

- desvelamento;

- releitura e engajamento numa nova forma de ação;

- rachaduras com que a sociedade entra em transição;

- movimentos de emersão das massas;

- superação da cultura do silêncio;

- movimentos de emergência;

- ação cultural e revolução cultural;

- movimentos revolucionários;

- dialetização da denúncia e do anúncio;

- liderança revolucionária;

- menção aos revolucionários Guevara e Camilo Torres;

- ação cultural para a libertação, que se caracteriza pelo diálogo, pela problematização, e não ação cultural para a domesticação, que "sloganiza";

- desenvolvimento tecnológico como um dos aspectos do projeto revolucionário;

- comunhão entre líderes e massas populares.

E, para fechar o texto, Freire alude a Marx: "las circunstancias se hacen cambiar precisamente por los hombres" e diz que "a conscientização é um esforço através do qual, ao analisar a prática que realizamos, percebemos em termos críticos o próprio condicionamento a que estamos submetidos" (Freire, 2001a, p. 77-100 grifos meus).

No texto que segue na mesma obra que vim citando, "O processo da alfabetização política: uma introdução", escrito em Genebra em 1970, Freire (2001a, p. 103) trata do analfabetismo político e da alfabetização política, distinguindo dois tipos de práticas: a domesticadora e a libertadora. A propósito, permito-me uma digressão. A prática domesticadora, mesmo que provavelmente não tenha sido invenção dos portugueses, foi inaugurada nesta terra com a chegada deles, como bem relata Pero Vaz de Caminha em sua carta ao rei de Portugal, referindo-se aos habitantes estranhos aqui encontrados: "Tudo se passa como eles querem, para os bem amansarem" (Caminha apud Amado, Figueiredo, 2001, p. 99).

Se, do ponto de vista linguístico, analfabeto é aquele que não saber ler e escrever, o analfabeto político, segundo Freire, "é aquele ou aquela que tem uma percepção ingênua dos seres humanos em suas ligações com o mundo, uma percepção 
ingênua da realidade social que, para ele ou ela, é um fato dado, algo que é e não que está sendo". É alguém que procura refugiar-se na falsa segurança do subjetivismo e na entrega a "práticas puramente ativistas". Em contraposição a esse analfabetismo político, a educação do ponto de vista crítico seria aquela em que educadores e educandos, através de um processo de desmitologização da realidade, se ajudem na superação do analfabetismo político. Para o autor, um dos ângulos importantes da conscientização deverá ser o de "provocar o reconhecimento do mundo": "não como um 'mundo dado' mas como um mundo dinamicamente 'dando-se'". A conscientização deve ter um caráter permanente (Freire, 2001a, p. 105-108).

Tratando do papel educativo das igrejas na América Latina, Freire adverte que "não há humanização sem libertação, assim como não há libertação sem a transformação revolucionária da sociedade de clamas [classes, conforme a $4^{\mathrm{a}}$ edição]". E acrescenta que "a libertação é o 'inédito' viável das classes dominadas", coisa que só se concretizará "na ultrapassagem daquela sociedade e não na simples modernização de suas estruturas" (Freire, 2001a, p. 142). Isto dito num período histórico em que as teorias da modernização eram moda!

Se as ideias, textos e práticas anteriores já incomodavam, a publicação da Pedagogia do oprimido em 1970 só fez aprofundar ainda mais esse sentimento de parte da ditadura militar e de seus apoiadores. Isto no ano em que o Mobral entrava em operação, tentando, inclusive, valer-se, não do Método, mas do método no sentido das técnicas de alfabetização de Freire, retiradas, porém, de seu contexto filosófico e político, o que Bárbara Freitag (1980, p. 93 - grifo da autora) interpreta assim: "Podemos dizer que o método foi refuncionalizado como prática, não de liberdade, mas de integração ao 'Modelo Brasileiro' ao nível das três instâncias: infraestrutura, sociedade política e sociedade civil".

A propósito, Gilberta M. Jannuzzi desenvolve a ideia de um confronto pedagógico entre Paulo Freire e Mobral (1983). Haveria apenas que ressalvar que esse confronto não era apenas pedagógico, bastando, para isso, lembrar a incomodativa e até ameaçadora dedicatória do livro: "Aos esfarrapados do mundo e aos que neles se descobrem e, assim descobrindo-se, com eles sofrem, mas, sobretudo, com eles lutam" (Freire, 1979, p. 17). Mas, além da dedicatória, havia outros elementos no livro que só podiam incomodar as elites e os blindados que as serviam. A começar pelo título: Pedagogia do oprimido. Depois, pelas sucessivas referências, nessa obra, a textos de Marx, de Marx e Engels, de Mao Tse Tung, de Lukács, de Althusser, de Guevara... Enfim, pelo conteúdo em si do livro, que Ernani Maria Fiori (1979, p. 1) sintetiza no próprio título de seu prefácio: "Aprender a dizer a sua palavra". Poderia haver coisa mais incomodativa, ameaçadora, do que alguém propor-se a ensinar ou a levar uma pessoa oprimida a aprender a dizer a sua palavra numa sociedade em que, historicamente, nunca coube ao povo mais que ouvir? "A educação libertadora - diz Fiori -, é incompatível com uma pedagogia que, de maneira consciente ou mistificada, tem sido prática da dominação". E acrescenta: "A prática da liberdade só encontrará adequada expressão numa pedagogia em que o oprimido tenha condições de, reflexivamente, descobrir-se e conquistar-se como sujeito de sua própria destinação histórica." Repete também as ideias freireanas de que 
"alfabetizar é conscientizar" e de que é com a palavra que o homem se faz homem: "Ao dizer a sua palavra, pois, o homem assume conscientemente sua essencial condição humana" (Fiori, 1979, p. 3-7).

Freire diz que a pedagogia do oprimido, como pedagogia humanista e libertadora, terá dois momentos distintos. O primeiro é aquele "em que os oprimidos vão desvelando o mundo da opressão e vão comprometendo-se na práxis com a transformação"; já o segundo é aquele "em que, transformada a realidade opressora, esta pedagogia deixa de ser do oprimido e passa a ser a pedagogia dos homens em processo de permanente libertação" (Freire, 1979, p. 44).

$\mathrm{O}$ autor tem consciência de que, ante a ameaça constituída pela rebeldia das massas, as elites dominadoras "têm o seu remédio em mais dominação" (Freire, 1979, p. 75). Atestam isto a história toda do País e, em particular, a da repressão durante a ditadura que se seguiu ao golpe de 1964. Mas há que se reconhecer que não faltaram intelectuais imaginativos que buscassem remédio também em mais mistificação. Vale lembrar aqui três obras que nem sob encomenda poderiam expressar melhor essa mistificação. Duas do economista e ex-ministro Mário Henrique Simonsen (1969, 1973), criador e primeiro presidente do Mobral; a terceira, do engenheiro Arlindo Lopes Corrêa (1979), do Instituto de Pesquisas Econômicas Aplicadas (Ipea) e segundo presidente do Mobral.

Em Brasil 2001, Simonsen (1969, p. 237), depois de uma análise do problema educacional brasileiro, anunciava uma mensagem de esperança, a saber, que lhe restava o consolo de ver que "nem tudo estava perdido no sistema educacional brasileiro": se o Ministério da Educação andara "emperrado pela arteriosclerose", pelo menos o Ministério do Planejamento, através do Ipea, "conseguira equacionar o problema nos devidos termos", isto é, transformar o problema educacional em prioridade, e isto, graças aos esforços de um grupo de engenheiros e economistas, entre os quais, Arlindo Lopes Corrêa, que o sucedera na presidência do Mobral.

Em Brasil 2002, o mesmo Simonsen (1973), ainda que reconhecendo que "não é elegante lamber a própria cria", dedicava várias páginas ao Mobral, reveladoras da concepção tecnocrática que estava na base dessa nova criatura, à qual estranhamente se quis dar o nome de Movimento. Ilustram bem essa concepção os três pontos que, segundo o seu ex-presidente, norteavam a atuação desse órgão, com destaque para a necessidade de se "reduzir ao mínimo os custos por aluno". Uma coisa que o autor não diz é quem e como iria operar o milagre de conciliar tudo isso:

a) a obtenção de material didático atrativo e de baixo custo;

b) a ampla descentralização administrativa, com a transferência das funções executivas para as Comissões Municipais;

c) o desenvolvimento de esquemas operacionais simples e padronizados, capazes de tornar logisticamente viável um programa de alfabetização de larga escala, e de reduzir ao mínimo os custos por aluno. (Simonsen, 1973, p. 147-148).

Nessa ótica, ficava arredado de qualquer consideração não só o que os intelectuais dos movimentos populares chamavam de conscientização e politização 
no processo de alfabetização, mas também a discussão a respeito do próprio sentido da alfabetização. Na perspectiva mobralina, a questão era de ordem meramente técnica, afastando-se, assim, in limine, a discussão sobre o significado do analfabetismo e o sentido da alfabetização.

No entanto, a obra que melhor expressa a mistificação então operada em torno da questão da alfabetização é Educação de massa e ação comunitária, editada pelo segundo presidente do Mobral, Arlindo Lopes Corrêa. Destaca-se, nessa obra, o primeiro capítulo: "Mobral: pedagogia dos homens livres", de autoria do próprio Corrêa, numa contraposição clara à obra Pedagogia do oprimido de Freire. Ali, depois de inaugurar o texto com a afirmação de que o Mobral era "um organismo vivo, em plena evolução", o autor, fazendo alusão à teoria da evolução de Darwin, talvez em busca de crédito para as suas ideias, sustenta nada menos do que isto:

Com a vida iniciou-se a evolução biológica, partindo da primitiva bactéria anaeróbia até chegar as [às] suas formas superiores. [...]

Assim, a entrada em operação do Mobral pode situar-se em analogia ao aparecimento da humilde bactéria anaeróbia, marco do surgimento da vida sobre a Terra e que, graças a um processo evolutivo empolgante, deu origem às suas formas mais complexas. (Corrêa, 1979, p. 18, 21 - grifo do autor).

Por fim, uma citação que põe a nu o caráter mistificador do Mobral em contraposição à pedagogia do oprimido de Freire: "Nossa educação - diz Corrêa - é verdadeiramente democrática: mostramos a verdade e as pessoas fazem livremente as suas opções". E acrescenta: "À 'pedagogia dos oprimidos' preferimos a 'pedagogia dos homens livres'" (Corrêa, 1979, p. 51). Prova cabal de que a alfabetização, mesmo se realizada sob a orientação ou direção do Mobral, estava longe de reduzir-se a uma questão de domínio meramente técnico da leitura e da escrita. Mais que a técnica, o que estava em disputa no confronto entre o Mobral e Freire era o sentido do ensinar e do aprender a ler e escrever.

Não vem ao caso estender-me aqui numa avaliação detalhada das realizações do Mobral, até porque já fiz isto, há um quarto de século, no artigo "Escola e produção do analfabetismo" (Ferrari, 1987), assunto retomado recentemente no Capítulo 5 - "Mobral: a 'pedagogia dos homens livres' da Ditadura Militar" - do livro História inacabada do analfabetismo no Brasil (Ferraro, 2009). Basta lembrar que a avaliação feita pelo Mobral de suas realizações foi desmentida pelo Instituto Brasileiro de Geografia e Estatística (IBGE). Segundo seus técnicos, no curto período de 1970 a 1977, o Mobral teria alfabetizado 11,3 milhões de pessoas de 15 anos ou mais, reduzido seu número de 18,1 milhões para 9,5 milhões e seu percentual de 33,6\% para 14,2\% (Costa, Barberá, Cordeiro apud Corrêa, 1979, p. 447-449). Três anos mais tarde, o Censo Demográfico realizado pelo IBGE em 1980 acusaria nada menos do que 18,7 milhões e uma taxa de 25,5\% de analfabetos entre as pessoas de 15 anos ou mais, número e taxa quase duas vezes mais elevados dos que os anunciados pelos técnicos do Mobral para o ano de 1977. Concluindo: ou o diagnóstico de Simonsen, que identificava arteriosclerose no Ministério da Educação, estava equivocado, ou padeciam do mesmo mal os economistas e engenheiros do Ipea em quem ele depositava esperança de salvação. 
Há outro ponto em que gostaria de tocar, mesmo que muito brevemente. Trata-se de como tomei conhecimento de Freire e da razão por que praticamente o ignorei em minha tese de doutorado sobre o Movimento de Natal (Ferrari[o], 1968).

Depois de oito anos de estudo em Roma e decorrido já um ano desde a experiência de Angicos, eu regressava ao Brasil para a realização de pesquisa sobre o Movimento de Natal para a minha tese de doutorado em Ciências Sociais na Pontifícia Universidade Gregoriana. Desembarcando no Porto de Santos no dia 19 de março de 1964, dirigi-me a São Paulo e, de lá, em seguida, ao Rio de Janeiro, a fim de pesquisar a bibliografia sobre o Nordeste, para o que me valeria das bibliotecas do IBGE e da Conferência Nacional dos Bispos do Brasil (CNBB). Foi na tarde do dia $1^{\circ}$ de abril de 1964, retornando de um dia de trabalho em biblioteca no Morro de Santa Teresa, que tomei conhecimento do golpe militar. No dia 3, segui para a cidade do Recife, onde fui acolhido pela equipe de Dom Hélder Câmara. O clima era de consternação. No dia 7 , cheguei à cidade de Natal para dar início à pesquisa. Pude entrar imediatamente em contato com Dom Eugênio Sales e sua equipe de colaboradores nas mais diversas atividades reunidas sob o nome de Movimento de Natal. Pude também estabelecer logo contato com duas instituições que foram de grande valia para o meu trabalho: a Fundação José Augusto, onde contei com inestimável apoio em termos de espaço físico e equipamentos para a pesquisa, datilografia, composição e publicação da tese; e a Universidade Federal do Rio Grande do Norte, particularmente na pessoa de seu vice-reitor, o Dr. Otto Guerra, pai do acadêmico Marcos Guerra, que, como já referido neste texto, participara, com Paulo Freire, da experiência de Angicos no ano anterior, ambos já às voltas com a repressão. Otto Guerra foi um interlocutor valioso em todo o tempo de minha permanência em Natal.

Nas diversas áreas do Movimento de Natal falava-se muito de Freire, de seu método de alfabetização, de conscientização, de politização, de palavras geradoras... Com o intuito de não comprometer o meu doutorado, que dependia não só da conclusão, mas também da publicação e remessa de trinta exemplares da tese à Pontifícia Universidade Gregoriana, reduzi as minhas considerações explícitas sobre Freire na tese à seguinte nota de rodapé no Capítulo IV:

(5) Veja, por exemplo, a Cartilha do MEB de Natal - Educar para Construir, Gráfica do SAR, Natal, 1964, 68p. Por medidas de prudência, esta Cartilha não foi distribuída. Pouco antes da Revolução havia sido apreendida no Rio [de Janeiro] uma Cartilha do MEB nacional, que tivera a aprovação da Comissão Episcopal que representava a CNBB [Conferência Nacional dos Bispos do Brasil] junto ao MEB. Quando não diretamente envolvidos em IPMs (Inquéritos Policiais-Militares), autor e seguidores do Método de Alfabetização "Paulo Freire" (inclusive elementos da equipe nacional e de equipes do MEB de vários estados) eram tidos, entre os da "linha dura" do novo governo, como suspeitos de subversão. (Ferrari[o], 1968, p. 104).

Esta nota de rodapé foi escrita no sentido de esclarecer duas coisas: que a educação de base, objetivo do ensino radiofônico realizado pelo MEB, "visava não somente a alfabetização, mas também a conscientização e politização [...] das populações rurais", e que o próprio método de alfabetização era um processo de conscientização e politização, na medida em que partia não das tradicionais cartilhas 
de alfabetização, mas de termos como povo, voto, liberdade, libertação, trabalho, salário, direito, etc. (Ferrari[o], 1968, p. 104).

Na realidade, não foi preciso referir Paulo Freire para que o autor de Igreja e desenvolvimento: o Movimento de Natal e do presente artigo merecesse algumas fichas dos agentes do Departamento de Ordem Política e Social (Dops) no Rio Grande do Sul, com destaque para aquela datada de 23 de agosto de 1971, com a seguinte anotação: "esteve no NE [Nordeste], tem-se notícias que é pertencente a política de Don Elder Camara, é autor do livro 2 IGREJA E DESENVOLVIMENTO altamente subversivo. Que foi editado em 69 e indiciado por isso em $71[\ldots]^{\prime \prime}{ }^{3}$

A propósito, cabe uma retificação: o livro fora publicado pela Fundação José Augusto, em Natal, no final de 1968. Um churrasco e um barril de chope haviam conseguido apressar os trabalhos, assegurando a entrega de 200 exemplares da tese ao autor na manhã do dia 13 de dezembro de 1968, algumas horas antes do Ato Institucional $\mathrm{n}^{\circ} 5$ - o golpe dentro do golpe -, exemplares esses que ficaram escondidos num porão, em Natal, até início dos anos 1980, com exceção de 30 que foram levados por terra até o Rio de Janeiro, de onde, graças à ajuda de amigos, puderam ser remetidos pelo correio para a Pontifícia Universidade Gregoriana, em Roma, para a obtenção do título de doutor em Ciências Sociais.

Penso que tudo o que disse até aqui permite entender por que o movimento golpista de 1964 tinha medo tanto dos movimentos sociais do final dos anos 1950 e início dos anos 1960, quanto de experiências como a de Angicos. O que talvez os golpistas não conseguissem captar é que a própria repressão movida contra esses movimentos e experiências pudesse estar sinalizando o caminho, mesmo que para um futuro distante!

Último ponto. No primeiro capítulo de História inacabada do analfabetismo no Brasil (Ferraro, 2009), eu dizia que, a contar das últimas décadas do século 19, quando o analfabetismo se transformara, quase que de repente, num problema nacional, se haviam sucedido "inúmeros discursos, juras, projetos, campanhas e até declarações de guerra contra o analfabetismo, acompanhados de periódicas reformas de ensino". Dizia também que, de tais esforços voltados para a escolarização e alfabetização do povo, haviam resultado, inegavelmente, "alguns avanços reais que se traduziram em alargamento da escolarização e em queda lenta, porém continuada, das taxas de analfabetismo, durante todo o decorrer do século 20". Mas acrescentava que, mesmo levados em conta tais esforços e avanços, permanecia de pé um fato inegável, a saber, que o Brasil findara o século 20 e adentrara no século 21 com um número verdadeiramente preocupante de pessoas ainda não alfabetizadas 17.552.115 entre a população de 10 anos ou mais. Se incluídas as crianças de 8 e 9 anos que ainda não haviam aprendido a ler e escrever (1.282.396), o total de analfabetos superava, em 2010, os 18,8 milhões (Ferraro, 2009, p. 25).

\footnotetext{
3 Já estava redigindo este artigo quando o jornalista Humberto Trezzi, membro de uma equipe do jornal Zero Hora, de Porto Alegre, me telefonou dizendo que localizara algumas fichas com o meu nome no Dops, coisa de que suspeitava, mas que nunca tinha averiguado. A citação foi retirada de cópias que foram remetidas para o meu e-mail pelo referido jornalista. Em 2 de junho de 2013, quando já estava concluindo este artigo, o Zero Hora publicou um caderno de oito páginas, sob o título "Os fichados do Dops no RS" e o subtítulo "ZH revela quem eram os 4,6 mil nomes vigiados pela ditadura no estado". Essa reportagem e essas 4,6 mil fichas podem ser acessadas em: zhora.co/DopsRS.
} 
Decorridos dez anos, o Censo Demográfico 2010, ao mesmo tempo em que confirma a continuidade da queda do analfabetismo no País, também mostra que essa queda continua lenta, deixando como desafio para os próximos anos (ou décadas?) um total de 14,6 milhões de pessoas de 10 anos ou mais ainda não alfabetizadas, número este que se eleva para quase 15,4 milhões, se incluídas as crianças de 8 e 9 anos que ainda não tinham aprendido a ler e escrever (IBGE, 2010).

O que acabo de dizer pode levar a que se pergunte se é justo chamar de analfabetas crianças de 8 e 9 anos que não tenham ainda aprendido a ler e escrever. Responderia que, como ensina Freire, se o termo "analfabeto" não deveria ser usado para jovens nem para adultos, com mais razão não deveria ser aplicado a crianças, pelo simples motivo que esse termo rotula, marca negativamente, estigmatiza. No entanto, não se pode ignorar o fato de que, hoje, crianças de 8 e 9 anos que não tenham conseguido ainda vencer essa primeira barreira no processo da escolarização, já levam consigo essa marca negativa da ignorância, da incapacidade, do fracasso escolar, ou, para usar a expressão que deu título ao conhecido livro de Envin Goffman (1988), o estigma do analfabetismo. Com efeito, como mostrado em estudo recente apoiado em dados do Censo 2000 (Ferraro, 2011, p. 993-995, 1009), "as desigualdades [regionais, no caso] quanto à alfabetização e à continuidade nos estudos se definem na largada do processo de escolarização fundamental", começando tais desigualdades a delinear-se já entre as crianças de 6 anos de idade, ampliando-se e definindo-se dos 6 para os 7 anos e encontrando-se já consolidadas para as crianças de 8 anos.

A preocupação com o analfabetismo infantil não constitui novidade. A própria Unesco, em estudo do início da década de 1950, fazia uma observação de sumo interesse sobre o analfabetismo infantil no Brasil:

É preocupante constatar que, no Brasil, a proporção de analfabetos entre as crianças em idade escolar (de 7 a 14 anos) é mais elevada do que entre os habitantes de mais de 15 anos, se bem que a taxa de diminuição do analfabetismo seja um pouco mais elevada no primeiro do que no segundo grupo. (Unesco, 1953, p. 42).

Vale também lembrar a manifestação mais recente em que Rosa Maria Torres (1990, p. 513) sustenta que a redução do problema do analfabetismo à população adulta (de 15 anos ou mais) explica a dificuldade real que se tem para assumir o analfabetismo como "uma problemática enraizada na escolaridade infantil, vinculada às deficiências de acesso e qualidade da escola primária".

É por isso que venho insistindo na necessidade de se voltar a atenção também para o fenômeno do analfabetismo infantil, por entender que a solução desse problema está na escolarização universal obrigatória e gratuita: a educação fundamental e, a partir da Emenda Constitucional no 59/2009, que tem o ano de 2016 como limite, a educação básica, entendida como o conjunto da educação infantil, fundamental e média.

No entanto, em países que não conseguiram ainda resolver o problema do analfabetismo, como o Brasil, há necessidade de uma segunda linha de ação, voltada para os jovens e adultos que não tenham sido alfabetizados na idade própria. São sujeitos desse tipo de ação todas as pessoas jovens e adultas não alfabetizadas, a 
contar dos 15 anos de idade. A contar dos 18 anos, na medida em que se for aplicando a já referida Emenda Constitucional, que estabelece 2016 como data limite para a escolarização universal obrigatória dos 4 aos 17 anos.

Admite-se que a alfabetização no sentido bem elementar de ler e escrever um bilhete simples, como definida nas pesquisas conduzidas pelo IBGE, não é mais que o primeiro passo na caminhada escolar. Mas é o primeiro passo, indispensável, que um número significativo de crianças e adolescentes continuam não conseguindo dar.

No fundo, como dizia o pesquisador polonês Józef Pólturzycki (1987, p. 287), há um quarto de século, referindo-se à experiência de seu país, trata-se, de um lado, "de assegurar que todas as crianças e adolescentes em idade escolar passem pelo sistema educacional" de sorte a "reduzir a formação de novas coortes de analfabetos e iletrados", e de outro, de construir um sistema de educação de adultos [jovens e adultos] "fortemente desenvolvido". Por fortemente desenvolvido, entenda-se um programa que, no mínimo, não se limite à alfabetização.

Para se ter noção do tamanho do desafio que está posto e da tarefa que nos aguarda ainda, no Brasil, basta lembrar aqui o número de pessoas contabilizadas pelo Censo Demográfico 2010 como não sabendo ainda ler e escrever nos seguintes grupos de idade: 15 a 19 anos - 373,6 mil; 20 a 24 anos - 477,5 mil; 25 a 29 anos - 678,8 mil; 30 a 34 anos - 921,5 mil; 35 a 39 anos - 1,023 milhão. Quase 3,4 milhões de pessoas por alfabetizar só nas faixas de 15 a 39 anos. Se quisermos incluir todas as pessoas não alfabetizadas dos 15 aos 49 anos, essa conta ultrapassará os 5,9 milhões. Para toda a população de 15 anos ou mais (jovens e adultos) serão13,9 milhões (IBGE, 2010).

Há que lembrar que seria desolador, se se voltasse a buscar solução para o problema do analfabetismo seguindo receitas do tipo daquela ditada pelo primeiro presidente do Mobral, já citada (Simonsen, 1973, p. 147-148), a qual pode ser assim esquematizada: material didático atrativo e de baixo custo; ampla descentralização administrativa; esquemas operacionais simples e padronizados, capazes de viabilizar um programa de alfabetização de larga escala e a um custo mínimo por aluno! Pensar num caminho como esse, seria dar atualidade à denúncia feita por Joaquim Nabuco na Câmara dos Deputados em 1879, em debate sobre a introdução do voto direto no Império:"[...] no orçamento tudo avulta, menos a instrução pública" (Nabuco, 1879, p. 201-206).

Finalizando, reafirmo a convicção de que as ideias, concepções, escritos e experiências de educadores, movimentos sociais e inclusive de alguns governantes do final dos anos 1950 e início dos anos 1960, que foram brutalmente reprimidos, por mais de duas décadas, pela ditadura implantada com o golpe de 64, mantêm-se vivos como fonte de inspiração para o enfrentamento do velho desafio da universalização da alfabetização, quando a legislação já determina a universalização da educação básica até 2016. 


\section{Referências Bibliográficas}

AMADO, Janaína; FIGUEIREDO, Luiz Carlos. Brasil 1500: quarenta documentos. Brasília: Ed. UnB; São Paulo: Imprensa Oficial do Estado de São Paulo, 2001.

AQUINO, Rubin Santos Leão de et al. Sociedade brasileira: uma história através dos movimentos sociais. 2. ed. Rio de Janeiro: Record, 2000. v. 1

AQUINO, Rubin Santos Leão de et al. Sociedade brasileira: uma história através dos movimentos sociais - da crise do escravismo ao apogeu do neoliberalismo. 3. ed. Rio de Janeiro: Record, 2002. v. 2

BALEEIRO, Aliomar. Constituições brasileiras: 1891. Brasília: Senado Federal, Ministério de Ciência e Tecnologia, Centro de Estudos Estratégicos, 2001.

BRASIL. Constituição (1988). Emenda Constitucional no 59, de 11 de novembro de 2009.[...] dá nova redação aos incisos I e VII do art. 208, de forma a prever a obrigatoriedade do ensino de quatro a dezessete anos [...]. Diário Oficial da União, Brasília, Seção 1, p. 8, 12 nov. 2009. Disponível em: < http://www.planalto.gov.br/ ccivil_03/constituicao/Emendas/Emc/emc59.htm>. Acesso em: 13 jun. 2013.

CORRÊA, Arlindo Lopes. Mobral: pedagogia dos homens livres. In: CORRÊA, Arlindo Lopes (Ed.). Educação de massa e ação comunitária. Rio de Janeiro: AGGS, Mobral, 1979. p. 15-58.

CUNHA, Euclides da. Os sertões. In: SANTIAGO, Silviano (Org.). Intérpretes do Brasil. Rio de Janeiro: Nova Aguilar, 2002. v. 1, p. 169-606.

FÁVERO, Osmar. Uma pedagogia da participação popular: análise da prática educativa do MEB - Movimento de Educação de Base (1961-1966). Campinas, SP: Autores Associados, 2006.

FERRARI[O], ${ }^{4}$ Alceu Ravanello. Igreja e desenvolvimento: o movimento de Natal. Natal, RN: Fundação José Augusto, 1968.

FERRARI[O], Alceu Ravanello. Escola e produção do analfabetismo. Educação \& Realidade, Porto Alegre, v. 12, n. 2, p. 81-96, jul./dez. 1987.

FERRARO, Alceu Ravanello. Movimento de Natal e a indústria das secas: 1958. In: FERRARO, A. R.; RIBEIRO, Marlene. Movimentos sociais: revolução e reação. Pelotas, RS: Educat, 1999.

FERRARO, Alceu Ravanello. Analfabetismo no Brasil: desconceitos e políticas de exclusão. Perspectiva, Florianópolis, v. 22, n. 1, p. 111-126, jan./jun. 2004.

FERRARO, Alceu Ravanello. História inacabada do analfabetismo no Brasil. São Paulo: Cortez, 2009.

\footnotetext{
${ }^{4}$ Ver nota 1.
} 
FERRARO, Alceu Ravanello. R. A trajetória das taxas de alfabetização no Brasil nas décadas de 1990 e 2000. Educação \& Sociedade, Campinas, v. 32, n. 117, p. 989-1013, out./dez. 2011. Disponível em: < http://www.scielo.br/pdf/es/v32n117/ v32n117a06.pdf>.

FERRARO, Alceu Ravanello; LEÃO, Michele de. Lei Saraiva (1881): dos argumentos invocados pelos liberais para a exclusão dos analfabetos do direito de voto. Educação Unisinos, São Leopoldo, RS, v. 16, n. 3, p. 241-250, set./dez. 2012.

FIORI, Ernani Maria. Aprender a dizer a sua palavra [Prefácio]. In: FREIRE, Paulo. Pedagogia do oprimido. 6. ed. Rio de Janeiro: Paz e Terra, 1979. Disponível em: <http://www.mda.gov.br/portal/saf/arquivos/view/ater/livros/Pedagogia_do_ Oprimido.pdf>. Acesso em: 28 nov. 2013.

FREIRE, Paulo. Pedagogia do oprimido. 6. ed. Rio de Janeiro: Paz e Terra, 1979.

FREIRE, Paulo. Ação cultural para a liberdade e outros escritos. 9. ed. São Paulo: Paz e Terra, 2001a. Disponível em: < http://www.dhnet.org.br/direitos/militantes/ paulofreire/paulo_freire_acao_cultural_para_a_liberdade.pdf $>$.

FREIRE, Paulo. Educação como prática da liberdade. 25. ed. Rio de Janeiro: Paz e Terra, 2001b. Disponível em: < http://forumeja.org.br/sites/forumeja.org.br/files/ eduliber.pdf $>$.

FREIRE, Paulo; GUIMARÃES, Sérgio. Aprendendo com a própria história. 2. ed. Rio de Janeiro: Paz e Terra, 2001.

FREITAG, Bárbara. Escola, estado e sociedade. 4. ed. São Paulo: Moraes, 1980.

GALVÃO, Ana Maria de Oliveira; DI PIERRO, Maria Clara. Preconceito contra o analfabetismo. São Paulo: Cortez, 2007.

GERMANO, José Willington. Lendo e aprendendo: "a campanha De Pé no Chão". São Paulo: Autores Associados, Cortez, 1982.

GÓES, Moacyr de. De Pé no Chão Também se Aprende a Ler (1961-1964): uma escola democrática. Rio de Janeiro: Civilização Brasileira, 1980. Disponível em: <http://www.dhnet.org.br/educar/penochao/livro_moacyr_de_pe_no_chao_1980. pdf> Acesso em: 28 nov. 2013.

GOFFMAN, Erving. Estigma: notas sobre a manipulação da identidade deteriorada. 4. ed. Rio de Janeiro: LTC, 1988.

INSTITUTO BRASILEIRO DE GEOGRAFIA E ESTATÍSTICA (IBGE). Censo demográfico 2000. Disponível em: <www.ibge.gov.br>. Acesso em: 7 jun. 2013.

INSTITUTO BRASILEIRO DE GEOGRAFIA E ESTATÍSTICA (IBGE). Censo demográfico 2010. Disponível em: <www.ibge.gov.br>. Acesso em: 6 jun. 2013. 
JANNUZZI, Gilberta S. de Martino. Confronto pedagógico: Paulo Freire e Mobral. 2. ed. São Paulo: Cortez, Autores Associados, 1983.

NABUCO, Joaquim. [Discurso]. In: CÂMARA DOS DEPUTADOS. Annaes da [...] sessão de 15/05/1879. Rio de Janeiro: Typographia Nacional, 1879. p. 199-208. Disponível em: <http://imagem.camara.gov.br/pesquisa_diario_basica.asp>. Acesso em: $1^{\circ}$ jan. 2007.

NOGUEIRA, Octaviano. Constituições brasileiras: 1824. Brasília: Senado Federal, Ministério de Ciência e Tecnologia, Centro de Estudos Estratégicos, 2001.

PAIVA, Vanilda P. Educação popular e educação de adultos: contribuição à história da educação Brasileira. São Paulo: Loyola, 1973.

PAIVA, Vanilda P. Um século de educação republicana. Pró-Posições, Campinas, v. 1, n. 2, p. 7-21, jul. 1990. Disponível em: < http://www.proposicoes.fe.unicamp. br/ $\sim$ proposicoes/textos/2-artigo-paivav.pdf $>$.

POLETTI, Ronaldo. Constituições brasileiras:1934. Brasília: Senado Federal; Ministério de Ciência e Tecnologia, Centro de Estudos Estratégicos, 2001.

PÓLTURZYCKI, Józef. Être alphabétisé et le rester: l'expérience polonaise. Perspectives: Revue Trimestrielle de l'Éducation, Unesco, v. 17, n. 2 (62), p. 287296, 1987.

ROSA, Geraldo Antônio da. O Contestado: a práxis educativa de um movimento social. Campinas, SP: Mercado das Letras, 2011.

SCOCUGLIA, Afonso Celso. Histórias inéditas da educação popular: do Sistema Paulo Freire aos IPMs da ditadura. João Pessoa: Ed. da UFPB; São Paulo: Cortez, Instituto Paulo Freire, 2001.

SIMONSEN, Mário Henrique. Brasil 2001. Rio de Janeiro: Apec, 1969.

SIMONSEN, Mário Henrique. Brasil 2002. 2. ed. Rio de Janeiro: Apec, 1973.

SOUZA, João Francisco de. A pedagogia da revolução. São Paulo: Cortez, 1987.

STRECK, Danilo. Angicos [verbete]. In: STRECK, Danilo; REDIN, Euclides; ZITKOSKI, Jaime José (Org.). Dicionário Paulo Freire. 2. ed. Belo Horizonte: Autêntica, 2010. p. 42-43.

TÁCITO, Caio. Constituições brasileiras: 1988. Brasília: Senado Federal; Ministério de Ciência e Tecnologia, Centro de Estudos Estratégicos, 2004.

TORRES, R. M. Analfabetismo y alfabetización en América Latina y Caribe: entre la inercia y la ruptura. Perspectives, Paris, v. 20, n. 4, p. 511-518, 1990.

UNESCO. L'analphabétisme dans divers pays: étude statistique préliminaire sur la base des recensements effectuées depuis 1900. Paris: Unesco, 1953. 
WANDERLEY, Luiz Eduardo. Educar para transformar: educação popular, igreja católica e política no Movimento de Educação de Base. Petrópolis: Vozes, 1984.

Alceu Ravanello Ferraro, doutor em Ciências Sociais / Sociologia, pela Pontifícia Universidade Gregoriana, de Roma (Itália), é docente convidado do Departamento de Estudos Básicos da Faculdade de Educação da UFRGS, desde 2010, atuando no Programa de Pós-Graduação em Educação com o apoio do Conselho Nacional de Desenvolvimento Científico e Tecnológico (CNPq).

aferraro@ufrgs.br

Recebido em 14 de outubro de 2013.

Aprovado em 6 de novembro de 2013. 